\title{
Does bank failure affect client firms? Micro evidence from Estonia
}

Karin Joeveer

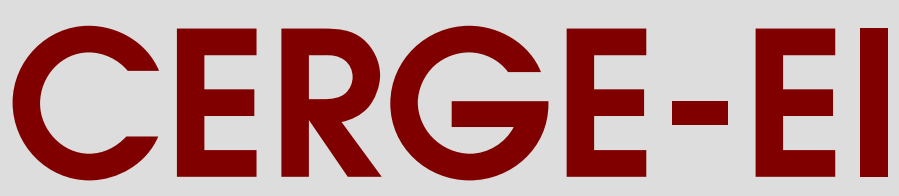

Charles University Center for Economic Research and Graduate Education Academy of Sciences of the Czech Republic Economics Institute 


\title{
Does bank failure affect client firms? \\ Micro evidence from Estonia
}

\author{
Karin Jõeveer \\ CERGE-EI \\ P.O. Box 882, Politickych veznu 7 \\ 11121 Prague 1 \\ Czech Republic \\ E-mail: karin.joeveer@cerge-ei.cz
}

May 2004

\begin{abstract}
I explore the effect of a bank's failure on its client firms using the 1998 bankruptcy of a middle-sized Estonian bank. I compare the performance of firms receiving credit from the bankrupt bank to that of a randomly selected set of firms between 1996 and 2000. I find the client firms to be less likely to survive until the end of the sample frame even after controlling for their performance before the bank bankruptcy.
\end{abstract}

\begin{abstract}
Abstrakt
Zkoumám vliv pádu banky na její klientské firmy na základe prípadu jedné zkrachovalé estonské banky strední velikosti v roce 1998. Porovnávám výkonnost firem získávající uver od zkrachovalé banky s výkonností náhodne vybraného vzorku firem mezi lety 1996 a 2000. Výsledky ukazují, že klienti této banky mají nižší pravdepodobnost prežití do konce pozorovaného období, a to i $\mathrm{v}$ prípade, že zohlednuji jejich výkonnost pred pocátkem financních problému banky.
\end{abstract}

JEL classification: G14, G21, G3

Keywords: Bank failure, client firm performance, firm bankruptcy.

\footnotetext{
* I am grateful to Štepán Jurajda for many valuable suggestions and patient reading of the earlier drafts of this paper. I am indebted for valuable comments to Ronald Anderson, Riku Kinnunen, Jan Svejnar and Tyler Shumway.
} 


\section{Introduction}

The bank-firm relationship, like any other lender-borrower relationship, involves asymmetry of information. This imperfection of the market allows firms to reap the cost advantage from long-term relationships with banks (Diamond (1991)). Hence it is natural to expect that the failure of a bank should affect its client firms' future performance due to the breakdown of the favored-credit channel.

Several studies, based on bank crashes in the U.S., Japan, and Korea (Slovin, Sushka, and Polonchek (1993), Gibson (1995), Kang and Stulz (2000), Yamori and Murakami (1999), Bae, Kang, and Lim (2002)) confirm this prediction and imply that the bank-firm relationship has an economic value. Furthermore, this effect apparently differs across countries according to the availability of equity financing. In particular, Ongena, Smith, and Michalsen (2003) do not find any effects of the banking crisis in Norwegian 1988-91 on firms' equity value. The authors explain this departure from the results typical for Japan or Korea by the fact that Norway firms were using relatively more public equity financing.

To-date there has been no empirical evaluation of the effect of bank failure on client firm performance in the context of a transition economy. This is surprising because the specific nature of transition economies makes this issue particularly important. First, bank failures are common in transition economies (Caprio and Klingebiel (1996), (2002)). Second, the majority of firms in transition countries are relatively young and lack reputation. Diamond (1991) suggests that such firms are more likely to depend on borrowing from banks as opposed to direct borrowing (issuing bonds or commercial 
papers). The stock markets are young as well and their level of activity is low (Grosfeld and Roland (1995)). Bank borrowing is therefore the main external financing channel in transition economies (Cornelli, Portes, and Schaffer (1996)). ${ }^{1}$ Further, empirical evidence from Korea (Bae, Kang, and Lim (2002)) implies that the failure of a bank has comparatively more severe effects on those firms that rely mainly on banks for their financing.

In this paper, I fill the gap in the literature by quantifying the value of the bankclient relationship in a transition economy - Estonia. Estonia is an important case to study for several reasons. First, it has had a currency board system since 1992 and therefore monetary policy has not been used to respond to money market difficulties. Estonia is also one of the most economically free countries in the world. ${ }^{2}$ Therefore this liberal policy has exposed Estonian firms to all international shocks. Second, Estonia had a banking crisis at the beginning of its transition period (1992-1995) ${ }^{3}$ and suffered another banking crisis in 1998. This study considers the latter crisis.

Estonia had twelve banks at the beginning of 1998 but only six at the end of the year. Eesti Maapank (The Land Bank of Estonia) was the first to disappear. ${ }^{4}$ It lost

\footnotetext{
${ }^{1}$ Calvo and Coricelli (1993) suggest that at least $20 \%$ of output collapse in early transition was explained by contraction in credit.

${ }^{2}$ Heritage Index of Economic Freedom 2003 (http://cf.heritage.org/index/indexoffreedom.cfm) placed Estonia in sixth position among 156 countries.

${ }^{3}$ For more details see Hansson and Tombak (1999) and Fleming, Chu, and Bakker (1996).

${ }^{4}$ Later, in the summer of 1998 two middle-sized banks merged with the two biggest banks in Estonia and in the fall, after the negative shock from Russia, two small banks went bankrupt and two other small banks merged.
} 
its license in June 1998 because of permanent insolvency. ${ }^{5}$ At the beginning of 1998, the bank was ranked the seventh largest based on total assets and covered $4 \%$ of the market. The first part of my sample consists of 119 firms which were clients of the Land Bank of Estonia.

These firms are not listed on the Estonian Stock Exchange. Hence, in contrast to earlier studies on bank failure effect on client firms, I am not able to quantify the effect on firms' equity values. This also means that the firms in my sample do not rely on public equity financing; bank loans are the main external source of finance. ${ }^{6}$ To measure performance I rely on information in the firms' balance sheets and income statements. To analyse the potential effect of bank failure on firm performance I use a comparison group of 114 randomly selected Estonian firms. Even though I do not have any information about the bank-specific lending relationship for my comparison group firms, I assume that the probability that they were clients of some other bankrupt bank is marginally small. ${ }^{7}$ The data cover the years $1996-2000$.

\footnotetext{
${ }^{5}$ The shareholders tried to recapitalize the bank in April 1998 but failed. The main reasons for insolvency were the mismanagement of loans' and securities' portfolio. The potential bad loan portfolio of the bank should be considered with caution because the direction of causality between the bank bankruptcy and firm bankruptcy is not clear. I address this issue in the analyses by controlling for the pre-bank bankruptcy financial characteristics of firms.

${ }^{6} 34 \%$ of firm financing came from internal resources in 1998 in Estonia. Domestic bank loans constituted $29 \%$ of total external financing of Estonian firms. Together with loans from the foreign sector the share of resources from banking is 51\% (Kangur, Rajasalu, and Randveer (1999)) compared to $66 \%$ in Japan and $39 \%$ in US (Gibson (1995)).

${ }^{7}$ The two other bankrupt banks covered together approximately $4 \%$ of the market (see also footnote $4)$.
} 
The unique data set allows to the following questions to be answered: Is the bankruptcy of the bank followed by bankruptcies of its client firms? Do firm performance measures deteriorate after their bank's bankruptcy compared to other firms? I answer "yes" to the first and "no" to the second question. Hence, while I detect a higher rate of bankruptcies among the failed bank clients I do not find a deterioration in the financial variables.

This paper is organized as follows. In the next section, I review theoretical and empirical studies of bank-firm relationship. In this section I also spell out my testable hypothesis. The data and methodology section follows. Section 4 presents the results. I conclude and discuss the policy implications in section 5.

\section{The bank-firm relationship reviewed and testable predictions}

The theoretical foundations of the benefits of the bank-firm relationship are pointed out by Diamond (1984). He stresses that financial intermediaries with a diversified asset portfolio are in better position to monitor borrowers and therefore are better off in overcoming the issue of asymmetric information. Diamond (1991) finds that firms which have long credit records — older firms with a long relationship with a bank — are exposed to cheaper borrowing. Those firms may find it also more beneficial to turn to the financial market directly — so their financing decisions are less dependent on bank credit. The firm choice between borrowing from a financial intermediary or directly from the market is considered also in Holmstrom and Tirole (1997). They show that 
only large firms can borrow directly from the market. Intermediate size firms borrow from banks and the smallest firms do not have any access to outside financing. The explicit inference of this is that large firms are more flexible in their borrowing decisions and they should find it easier to switch from one financier to another.

There is now extensive empirical literature evaluating the bank-firm relationship. Slovin, Sushka, and Polonchek (1993) explore the effect of the near failure of the Continental Illinois Bank in 1984. They identify the effect of bad news in the banking sector to the client firms equity value. They combine the loan clients of Continental Illinois Bank into a single portfolio and compare the return of this portfolio to the market portfolio. They find that firms, which have a borrowing relationship with the distressed bank, have significant negative excess returns in the period of bank difficulties, in this particular case in the two and half months before the rescue. The bank rescue announcement turned the excess returns positive, but they remained lower compared to the negative returns made at the time of bank distress.

Yamori and Murakami (1999) execute a similar study for the Japanese Hokkaido Takusyoku Bank in 1997. In addition they were able to answer the question whether the closeness of the relation with the failed bank had an effect on the firm, since in Japan firms report annually the banks they use in order of significance. Yamori and Murakami identify large negative abnormal returns to firms having a tighter relationship with the failed bank on the day of the bank failure and the day after. More generally the whole banking sector crash in Norway in 1988-91 with its influence to the firms is considered by Ongena, Smith, and Michalsen (2003). Surprisingly they find that firms' equity value slightly increased at the time of the crisis. Although banks were the major source 
of external financing in Norway, the banking distress did not damage the investment abilities of the firms. One of the explanations of the contrasting results compared to previous studies is that Norwegian firms were issuing on average new equity more often. $^{8}$

Another branch of the empirical literature detects what type of firms are more affected by a banking crises and whether we can identify a real effect (i.e. decrease in investment). Gibson (1995) finds that a firm's investment depends on its main bank's credit rating. The clients of lower rated banks invested less during the time of weakness of the banking sector in Japan in 1991-92. Beside looking at the bank characteristics Kang and Stulz (2000) show that a firm's performance during the banking crisis depends also on a firm characteristics like its financing structure. Firms that use mainly bank loans for financing investments invested less during the contraction of the Japanese banking industry at the beginning of the 1990's. Also the stock performance of more bank dependent firms is worse at the time of a banking crisis. Bae, Kang, and Lim (2002) find support for the previous hypothesis in the case of Korea in 1997-98. In addition they find that the financially weaker firms (e.g. less profitable) are more affected by the health of the banking sector.

The studies mentioned in the previous paragraph are more directly connected to my research agenda in that they do not concentrate narrowly on changes in stock prices and they deal with longer-term effects. In my study I consider the effect of bank failure on firm bankruptcy probability, and dependence on banks, leverage, liquidity, profitability,

\footnotetext{
${ }^{8} 33 \%$ of Norwegian firms issued equity in each year compared to $10 \%$ of Japanese firms (Ongena, Smith, and Michalsen (2003)).
} 
investments and efficiency. Based on theory and empirical studies I pose the following hypotheses: the bankruptcy of the bank increases the bankruptcy probability of the client firms, decreases client firms' dependence on banks, leverage, liquidity, profitability, and investments. The direction of the effect on efficiency measures is not certain. In Table 1, I summarize the testable predictions and the definitions of the financial ratios I use.

\section{$3 \quad$ Data and methodology}

The present analysis is focused on a bank bankruptcy, which occurred in June 1998 in Estonia. The analysis is based on an annual panel of loan clients of the bank under study and a random sample of Estonian firms. From now on, I will refer to those firms that were served by the bankrupt bank as the treatment group and the other firms as the control group. I use a 1997 sample of firms and follow their performance over time until 2000. My data also cover information form 1996 for some firms. The firms' balance sheets and profit statements were obtained from the Estonian Center of Register. This register collects reports of all Estonian firms on an annual basis. Each firm is legally required to report balance sheet and income statement data for each business year.

The 119 firms in my treatment group were drawn from a list of the 450 Land Bank clients. The sample selection was stratified randomly by industry. Industrial firms were over-sampled because this sector is considered to be less correlated with the business cycle compared to the trade and construction sectors, for example, and therefore the 
change in firm performance can be more directly assigned to bank failure. About $40 \%$ of the enterprises are from the industrial sector. The control group consists of 114 enterprises with similar turnover and industrial structure as the treatment group in 1997. The firms in my sample are privately owned with a few exceptions of municipally owned firms. Less than 10 firms are foreign owned. The lack of variability in my sample's ownership structure does not allow me to include the ownership variable in the following analyses.

Table 2 gives summary statistics for the firms in my sample in 1997, the start of my sample frame. The age structure of the firms in both groups is fairly similar. The average age is a little more than six years. The share of exporting firms is higher in the control group, where $53 \%$ of firms were involved in exporting their products versus $43 \%$ in the treatment group. The average profit and size are higher for the treatment group but the differences between groups are not statistically significant. In Section 4 I explore more deeply the differences between the financial ratios of the two groups of firms.

A first look at the data reveals significant firm attrition. The number of firms decreases during the sample frame due to firm bankruptcies. ${ }^{9}$ The decrease is larger for the treatment group where approximately 30\% of firms disappeared between 1997 and 2000 compared to the $10 \%$ drop in the size of the control group. Hence, it is important to explore whether this attrition is related to the bank failure. I analyze the survival

\footnotetext{
${ }^{9} 48$ firms stopped reporting their financial statements, out of them 29 went bankrupt, 4 were in the middle of the bankruptcy process and for 15 firms the reason of exit is unknown. The treatment of those 15 firms is explained in more detail in the "Results" section.
} 
of firm with a logit model conditioning on 1997 firm performance, that is performance before the bank crash. ${ }^{10}$ The method fits the linear logistic regression model for the binary data about firm existence in the year 2000 by the method of maximum likelihood. ${ }^{11}$ The vector of bankruptcy predictors consists of: firms' profitability, leverage, size in 1997, the industry (used to capture initial differences of firm performance); and the "treatment" dummy (captures the effect of the bank failure). I also estimate a duration model of firm exit hazard - the per-period probability of firm bankruptcy. ${ }^{12}$ This model allows me to focus on the timing (year) of the exit, which is important for detecting the lag between the bank failure and firm failure.

The next step is to analyse firms' performance (see Table 1) based on the information in their financial statements. I visualize the variables across the treatment and control group and execute the differences of means analysis to detect the possible different performance across the two groups of firms over time.

Finally, I use panel data estimation to detect support for the "treatment effect" on the firms' profitability, fixed assets growth rate, liquidity and leverage after conditioning on other time changing covariates and correcting for attrition bias. The decrease in my sample caused by firms' bankruptcies means that the sample is truncated based on the dependent variable, which biases least-squares coefficients. I address this problem by using the Symmetrically Trimmed Leased Squares estimation method (STLS) (Chay

\footnotetext{
${ }^{10}$ Ohlson (1980) was one of the first users of the logit analysis in the context of firm bankruptcy prediction.

${ }^{11}$ The binary dependent variable "Survival" has a value of 1 if the firm is still in my sample in the year 2000 and 0 if, by 2000, the firm was bankrupt or in the bankruptcy process.

${ }^{12}$ For details see Shumway (2001).
} 
and Powell (2001)). As I have already mentioned the observed values of the dependent variables are truncated and therefore the dependent variables have an asymmetric distribution. STLS restores symmetry by trimming the data from above, which allows one to estimate least-squares. The standard errors are bootstraped: based on 100 replications of the data the model is re-estimated revealing the variations of the coefficients. The estimated regression is of the following form:

$$
Y_{i t}=\alpha_{0}+\alpha_{1} \text { lnsale }_{i t}+\alpha_{2} \text { credit }_{i t}+\delta T_{i}+\beta D_{t}+\gamma D_{t} * T_{i}+\varepsilon_{i t},
$$

where $i=1$ to 233 is the firm index and $t=1$ to 5 is the year index. $Y$ is either profitability, growth of fixed assets, liquidity, or leverage. Insale is the logarithm of net sales (proxy for size) and credit is the total bank credit to assets ratio (proxy for bank dependence). $\varepsilon_{i t}$ is the symmetrically distributed error term. $D$ is the year dummy, $T$ is the treatment group dummy and $D * T$ is the interaction term between treatment and year dummies. The interaction term is calculated for the years 1998, 1999 and 2000 to capture the potentially different behavior of the treatment group after the bank crash. All specifications except the profitability regression include the profitability variable as an additional explanatory variable. Profitability and liquidity regressions include the leverage ratio as an extra explanatory variable. ${ }^{13}$ All regressions include industry dummies.

\footnotetext{
${ }^{13}$ It is found in the empirical studies of corporate leverage (Titman and Wessel 1988), investment (Kang and Stulz 2000) and liquidity (Kim, Mauer, and Sherman 1998) that the firm profitability is a significant explanatory variable as well as leverage being a significant explanatory variable for profitability (Joh 2003) and liquidity (Kim, Mauer, and Sherman 1998).
} 


\section{Results}

\subsection{Firm survival}

In this section I first estimate the probability of a firm surviving till the end of my sample frame. I ask whether the chances of survival are different for the failed bank clients compared to other firms. ${ }^{14}$ I estimate the logit model and control for the treatment dummy, a constant term, a set of industry indicators, and I also condition on 1997 firm-specific performance information. The results are presented in column (1) of Table 3.

The 1997 profitability variable (return on assets) has the expected positive sign. A $1 \%$ increase in the profitability ratio causes survival to increase by $0.14 \% ;{ }^{15}$ the coefficient estimate is significant at the $10 \%$ level. The leverage ratio has a negative estimate suggesting that more leveraged firms are more likely to disappear, but it is not precisely estimated.

The logarithm of sales is included in the regression in order to control for the size of the firm. ${ }^{16}$ The coefficient of this variable has a negative sign, suggesting that small firms are more likely to survive. This is a somewhat puzzling result because usually small firms are considered more likely to go bankrupt (Ohlson 1980). ${ }^{17}$

\footnotetext{
${ }^{14}$ I exclude the 15 firms for which I do not know the reason of exit.

${ }^{15}$ All the marginal effects in logit and later in hazard estimation are calculated at the means of the independent variables.

${ }^{16}$ Results are robust to using logarithm of total assets instead proxy of firm size.

${ }^{17}$ The negative coefficient in front of the logarithm of the sale variable might be accounted for the restructuring of the large Soviet-time firms (see also footnote 18 for more details). To allow the
} 
I also test for the effect of firm age. Column (1) in Table 3 includes a dummy for the youngest firms, established in 1996-97. The coefficient of this variable has a significant negative value. The firms established in 1996-97 are $19 \%$ more likely to go bankrupt than the firms established before $1996 .{ }^{18}$ This result is consistent with theoretical predictions (Diamond (1991)) as well as empirical findings (Westgaard and van der Wijst (2001)).

The treatment dummy has a significant negative effect on survival. The treatment firms are $17 \%$ more likely to go bankrupt compared to the control firms. This result means either that treatment firms are weaker firms than firms in the control group (but this weakness is not accounted for by the 1997 financial characteristics) or that the bank bankruptcy has had a negative effect on the treatment firms. Therefore it is important to understand the identifying variation of the significant 1997 profitability variable.

The lower profitability among treatment group firms would raise the possibility of reverse causality. A weak loan portfolio might have been the cause of the bank failure. distinction of the effect of bank bankruptcy across the size of the client firms I added to the unreported specification the interaction term between the treatment dummy and logarithm of the firm sales into the logit and hazard estimations. I find that the bankruptcy of the bank does not have a different effect across the size of the client firms.

${ }^{18}$ In unreported specification I also test (1) whether the large firms established during the Soviet time were more likely to be the ones which collapse after the bank bankruptcy (note that in my data I do not observe the renaming and the reorganization of the firms); (2) whether the firms with and without credit behave differently and (3) whether the exporting firms are more likely to go bankrupt after 1998. None of those hypotheses were supported by data. 
Investigating the profitability of firms across the two groups reveals that the variation comes from both groups and therefore it should capture initial differences in the quality of firms. The profit from normal operations which I use for calculating the profitability measure takes into account the interest expenses and therefore the low profitability measure might not be considered as a signal that the firm is not able to pay back the loan.

Another argument against the reverse causality story is provided by the Bank of Estonia's Banks Inspection report. In this report the Banks Inspectorate evaluated Maapank's last balance sheet. On the assets side an additional 12 million kroons were added for the provision of credits. At the same time shares and bonds were written off to the amount of 286.6 million kroons. This is direct evidence that the decline in the stock market at the end of 1997 was the main cause of the bank's loss of liquidity and not the inability of client firms to pay back their loans. The share of non-performing assets of Maapank were $2.3 \%$ in May 1998, which is only slightly higher than the Estonia banking sector average of $1 \%$ but still tiny compared to the other transition countries. ${ }^{19}$ Therefore I conclude that the causality runs from bank failure to firm failure.

To shed some light on the issue of bank failure as a trigger of firm failure, it is important to test when exactly the exit of the firms occurred. If treatment firms go bankrupt shortly after bank failure, this would help to support the hypothesis that the bank bankruptcy causes the client firm bankruptcy. I estimate a discrete-time logit-

\footnotetext{
${ }^{19}$ Most of the transition countries have two-digit non-performing loans figures see EBRD "Transition Report" (2001) for details.
} 
specification duration model where duration corresponds to years of firm presence in my sample. Duration models build upon the concept of a hazard function, which is defined as the probability of leaving a given state at a specific duration conditional upon staying there up to that point. Such a simple duration model boils down to a logit estimation using each year of firm presence in the data as one observation. ${ }^{20}$

In the duration analysis, each observation corresponds to a firms' submission of an end-of-year financial report to the Center of Register. ${ }^{21}$ The dependent variable has a value of 0 if a firm still exists in the next (year) period and equals 1 if a given firm exits the sample in the next period. ${ }^{22}$ I control for the differences in initial financial characteristics of firms by including the 1997 firm-specific data into my duration model. I also include year dummies (to absorb the economy-wide effects), and the interaction terms of treatment and year dummies. The last regressors are of interest since they detect whether the exit hazard for treatment firms is higher in some particular year after bank crash.

The results are reported in column (2) of Table 3. Initial firm profitability is negatively related to going bankrupt in the next period. Firms with high profit ratio are less likely to disappear but this coefficient is insignificant. More leveraged, large

\footnotetext{
${ }^{20}$ I do not consider unobservable heterogeneity in the duration model (Heckman and Singer 1984) due to the small amount of data available.

${ }^{21} \mathrm{My}$ sample was selected based on the firm existing in 1997. Therefore the 1996 data are conditional of firms existing in 1997 and are not useful in this estimation. I do have information about firm existence in 2001.

${ }^{22}$ For the 15 firms for which I do not have the reason of exit from my sample, I exclude (censor) the last year in which they were still reporting.
} 
and young firms are more likely to exit the sample confirming the results from the survival regression. The interaction terms are significant for 1997, 1998 and 1999. This means that treatment firms were more likely to exit than other firms in years 1998, 1999 and 2000. In year 2001 the interaction term is insignificant referring that the we do not observe anymore more frequent exit of treatment firms. Hence, hazard estimation confirms that treatment firms are more likely to go bankrupt and this effect is neutralized by time.

The analysis in this section confirms that treatment firms are more likely to go bankrupt compared to other firms. My analysis allows for the interpretation of this result as the effect of the bank failure. Hence, I find a real long term negative effect of bank failure on the economy. Compared to the studies based on bank failure in the US or Japan (Slovin, Sushka, and Polonchek (1993), Yamori and Murakami (1999)), which find negative returns to the failed bank client firms assets prices lasting a few days or weeks, the effect I find is more severe. The reason for the different size of the effect may be that Estonian firms in the study are smaller and more dependent on banking finance. Those firms do not use public equity and the main source of outside financing is bank credit. The result found might be magnified because of the change of environment. The bank failure in 1998 was shortly followed by the Russian crisis causing the general tightening of bank credit in Estonia in $1999 .{ }^{23}$ After studying the effect of bank failure on client firms' existence, below I analyse the effect of bank failure on surviving firms' financial ratios.

\footnotetext{
${ }^{23}$ Estonian total banking sector credit volume was 127, 164 and 151 billion 1997 Estonian kroons for 1997, 1998 and 1999 respectively.
} 


\subsection{Firm performance}

A simple visualization of the effect of bank bankruptcy on firms is provided in Figures 1-5, where the medians of main financial ratios are graphed over time separately the for treatment and control group of firms. ${ }^{24}$

The variables in the first group measure firm dependence on bank credits. The ratios in this group are short-term bank credit to total bank credit, total bank credit to total liabilities and total bank credit to total assets. The first ratio expresses the credit structure: the importance of the short-term credit. The other two ratios might be considered substitutes as both of them express the overall importance of credit in firm capital structure.

The second group of ratios involves the leverage measure; how much a firm relies on external finance. I calculate the leverage as total liabilities to total assets. This ratio may have value above one since several firms in several years in my sample have negative total owners' equity. In Figure 1 I plot the three bank dependence figures and leverage ratio. The importance of bank credit, short term credit and leverage have slightly decreased over time.

The third group of ratios are liquidity ratios. I use three liquidity measures. First is the current assets minus inventories to total assets, second is the current ratio, calculated as current assets to current liabilities and third is the quick ratio, calculated as cash to current liabilities. In Figure 2 we can see that all the different liquidity measures are fairly stable over time but different across the treatment and control

\footnotetext{
${ }^{24}$ I tried also to split the control group into two for capturing the possible different behavior of firms with and without credit but it did not reveal any additional insight.
} 
group of firms.

The fourth group of ratios are the profitability ratios. I look at 3 ratios - profit from normal operations to year average total assets, profit from normal operations to year average share capital and profit from normal operations to sales. I do not consider the ratio profit to equity due to the already mentioned negative equity problem. If both profit and equity are negative then the ratio will have a positive sign disturbing the distribution of the ratio since it is not possible to identify the reason why the ratio has a positive sign. From Figure 3 we can see that the profitability of the firms decreased until 1999, and in 2000 we can observe a recovery.

The fifth group of ratios are the growth ratios. I consider growth of total assets, inventories, fixed assets (as a rough proxy for investment) and sales. ${ }^{25}$ From Figure 4 we can see that growth rates have been slowing down. Differently from the others the sales growth rate in 2000 has recovered from the very modest 1999 result. The nonexisting growth in fixed assets in 1999 and 2000 is worrisome from a macroeconomic point of view.

The sixth group of ratios represents the so called activity or efficiency ratios. I consider two ratios here. First, the inventory turnover ratio, which is calculated as sales to average inventories. Second, the average collection period, which is calculated as average receivables to sales times 365 days. This measures lag between the sales date and payments received date. From Figure 5 we can see that the behavior of measures

\footnotetext{
${ }^{25} \mathrm{I}$ calculate the growth rate of variable $\mathrm{x}$ by the following formula: $\operatorname{growth}(x)=\left(x_{t}-x_{t-1}\right) /(0.5 *$ $\left.x_{t}+0.5 * x_{t-1}\right)$. The total assets, inventories, fixed assets and sales are expressed in 1997 prices.
} 
have been different across the two groups. ${ }^{26}$ The inventory turnover increased for the treatment firms while it decreased for the control firms. In other words treatment firms have gained efficiency while control firms have lost it. The lost of efficiency of control firms is even more apparent in the average collection period, which has more than doubled from 13 days in 1996 to 28 days in 2000.

Other studies on firm performance (Gibson (1995), Kang and Stulz (2000)) also make use of the seventh group of ratios - market ratios. These are price earning ratio and $\mathrm{Q}$ ratio, the market value of the firm to the replacement cost. However as mentioned before firms in my study are not publicly traded and therefore I lack information to calculate those ratios. Several studies use different efficiency measures than I do, e.g. sales to employment (Megginsion, Nash, and Randenborgh (1994)). Due to many missing values, employment data are not exploited in the current analysis.

The differences of the mean test confirms the visual observations. The importance of bank credit has decreased both for the treatment group firms as well as for the control group firms. The growth rate of fixed assets has also decreased for all firms. The change in the other variables over time is not significant. Based on this we cannot conclude that the bankruptcy of the bank has had an effect on client firms' financial ratios.

The differences of means analysis across treatment and control groups reveals the following. First, before 1998 firms in the treatment group were more leveraged. Hence, the treatment firms were more indebted. The difference in leverage disappears after

\footnotetext{
${ }^{26}$ Note that the scale of the variables is different. Inventory turnover ratio is measured in percentages and average collection period is measured in days.
} 
1998. Second, profitability was significantly lower for treatment firms before 1998 . After 1998 the mean of profitability of the two groups becomes insignificantly different due to the decrease of profitability in the control group. Third, liquidity has was smaller in both time periods for treatment firms. All other ratios of interest were not significantly different across the groups.

Based on comparison of the two groups we see that the treatment firms' financial characteristics are different from the control firms but we cannot detect any sign which would say that the performance of treatment firms deteriorated after their bank crash. It seems that even the initial, somewhat worse financial condition of treatment firms does not worsen their performance measures compared to other firms.

Note, that if the firm was bankrupt we do not see it anymore in the sample and it is not taken it into account in calculating the means of financial ratios. So the differences of means analysis is biased since the comparison samples are conditional on the firm's existence. This may explain the weakness of finding support for the negative effect of bank failure. To correct the possible bias I apply the STLS estimation methodology in the following regression analysis.

Besides correcting the sample selection bias the regression analysis of key financial characteristics also takes into account the contemporaneous changes in other control variables. I perform the panel estimation using four performance measures. The determinants of firm profitability, growth rate of fixed assets, liquidity, and leverage are the basic firm characteristics consistent with finance theory.

Table 4 presents the results of the STLS estimation of financial variables. ${ }^{27}$ For

\footnotetext{
${ }^{27}$ The STLS results are robust for the censoring level of the dependent variable.
} 
simplicity only the coefficients of the treatment dummy and interaction terms between treatment and year dummies are reported in Table 4 . The treatment dummy is a significant regressor in profitability and liquidity regressions. This supports the visual finding from Figures 2 and 3 and the differences of means analyses - the negative sign in front of the treatment dummy confirms that the treatment firms are less profitable and less liquid. In the profitability regression the coefficients of the 1999 and 2000 interaction terms with the treatment dummy are positive and significant. This may be interpreted as a decrease of profit differences across the two groups of firms: the initial profit disadvantage of treatment firms is decreasing over time. All the other interaction terms between the year and treatment dummies are insignificant inferring that the financial measures were not evolving differently across the failed bank clients and other Estonia firms after the bank bankruptcy.

Based on the STLS analyses we do not find that the bank bankruptcy has had any negative effect on firms performance indicators. Also we can conclude that the correction for survivorship bias and control for other variables did not change the results found in the raw differences in differences analyses.

\section{Conclusions}

This paper investigates the effect of bank failure on client firms performance. The study is based on a bank bankruptcy in Estonia in 1998. Since bank financing is a significant source of external funds for firms in countries undergoing market reforms, the question of the impact of bank failure is an important field of study. 
The research based on bank failures in the US and Japan shows that bad news about a bank causes a decrease in the client firms' stock price. The length of the effect varies from a few days to a few months. In my study the client firms are not listed on the stock market and I therefore use the yearly balance sheet data from 1996 to 2000 . I find that client firms are less likely to survive until the year 2000 compared to other firms. I consider different explanations for this result and conclude that the bank's bankruptcy was the reason why the firms went out of business. I find that young, more leveraged and large firms are more likely to fail. This suggests that bank dependence is an important issue in transition economies. The financial dependence detected in my paper is an additional incentive for monetary authorities to guarantee well-functioning financial systems.

The firms in my study are not directly comparable to the firms in the studies based on developed countries since my firms were not publicly traded. So they are smaller and more bank dependent. This raises the research question of whether the bank failure effect is different across listed and unlisted firms in developed countries.

I also study the effect on performance measures of firms. I did not detect any deterioration of profitability, leverage, liquidity or growth rate of fixed assets for the failed bank clients compared to the other firms. This might be explained by the fact that the accounting information is rigid and there is a time lag between the worsening of the firm's situation in the market and the entrance of this information into the accounting. Also the yearly reported firm financial statements may not reveal the possible short-term difficulties caused by the bank failure. The failed client firms may be particularly weak just before their bankruptcy but this information is not captured 
in the last balance sheet that I have.

This study relates to several research areas. The bank runs and banking crises literature has increased during the last two decades due to the increase in frequency of banking crises. Closely connected to this is the macroeconomic literature, that studies the different channels of financial disturbances to the real economy (Bernanke (1983)). Hence the bank-firm relationship is an important subject to study. More generally the financial development is considered as an important factor for promoting economic growth and hence the economic growth literature (Levine and Zervos (1998), Rajan and Zingales (1998), Filer, Hanousek, and Campos (1999)) is related to the present study. The analysis of firm performance and financial structure in my paper are essential to the corporate finance literature (Fazzari, Hubbard, and Petersen (1988)).

I find in my study that the bank firm relationship is valuable in the transition economy. The client firms are less likely to survive compared to other firms after loosing their bank. The severity of my result highlights the need for further studies on the issue of bank failure effects on client firms in financially less developed and more bank-dependent economies.

\section{References}

Bae, K.-H., J.-K. Kang, and C.-W. Lim, 2002, "The Value of Durable Bank Relationship: Evidence from Korean Banking Shocks," Journal of Financial Economics, 64, 181-214.

Bernanke, B. S., 1983, "Nonmonetary Effects of the Financial Crisis in the Propagation 
of the Great Depression," The American Economic Review, 73, 257-276.

Calvo, G. A., and F. Coricelli, 1993, "Output Collapse in Eastern Europe," IMF Staff Papers, 40.

Caprio, G., and D. Klingebiel, 1996, "Bank Insolvencies: Cross-country Experience," World Bank Policy Research Working Paper, 1620.

Caprio, G., and D. Klingebiel, 2002, "Episodes of Systemic and Borderline Banking Crises," World Bank Discussion Paper, 428, 31-49.

Chay, K. Y., and J. L. Powell, 2001, "Semiparametric Censored Regression Models," Journal of Economic Perspectives, 15, 29-42.

Cornelli, F., R. Portes, and M. E. Schaffer, 1996, "The Capital Structure of Firms in Central and Eastern Europe," Cepr Discussion Paper, 1392.

Diamond, D. W., 1984, "Financial Intermediation and Delegated Monitoring," Review of Economic Studies, 51, 393-414.

Diamond, D. W., 1991, "Monitoring and Reputation: The Choice between Bank Loans and Direct Placed Debt," Journal of Political Economy, 99, 689-721.

Fazzari, S. M., R. G. Hubbard, and B. C. Petersen, 1988, "Financing Constraints and Corporate Investment," Brookings Papers on Economic Activity, 1988, 141-195.

Filer, R., J. Hanousek, and N. Campos, 1999, "Do Stock Markets Promote Economic Growth," CERGE-EI Working Paper, 151. 
Fleming, A., L. Chu, and M.-R. Bakker, 1996, "The Baltics-Banking Crises Observed," World Bank Policy Research Working Paper, 1647.

Gibson, M. S., 1995, "Can Bank Health Affect Investment? Evidence from Japan," Journal of Business, 68, 281-308.

Grosfeld, I., and G. Roland, 1995, "Defencive and Strategic Restructuring in Central European Enterprises," Cepr Discussion Paper, 1135.

Hansson, A. H., and T. Tombak, 1999, "Banking Crises in the Baltic States: Causes, Solutions, and Lessons," in Mario I. Blejer, and Marko Skerb (ed.), Financial Sector Transformation: Lessons from Economies in Transition . chap. 5, pp. 195-236, Cambridge University Press.

Heckman, J., and B. Singer, 1984, "A method of minimizing the impact of distributional assumptions in econometric models for duration data," Econometrica, 52, 271320.

Holmstrom, B., and J. Tirole, 1997, "Financial Intermediation, Loanable Funds, and The Real Sector," Quarterly Journal of Economics, 112, 663-691.

Joh, S. W., 2003, "Corporate Governance and Firm Profitability: Evidence from Korea before the Economic Crisis," Journal of Financial Economics, 68, 287-322.

Kang, J.-K., and R. M. Stulz, 2000, "Do Banking Shocks Affect Borrowing Firm Performance? An Analysis of the Japanese Experience," Journal of Business, 73, 1-23.

Kangur, A., T. Rajasalu, and M. Randveer, 1999, "Kapitali liikumine ja ettevõtluse rahastamine," Eesti Panga Toimetised, 4. 
Kim, C.-S., D. C. Mauer, and A. E. Sherman, 1998, "The Determinants of Corporate Liquidity: Theory and Evidence," Journal of Finanial and Quantitative Analysis, $33,335-359$.

Levine, R., and S. Zervos, 1998, "Stock Markets, Banks, and Economic Growth," The American Economic Review, 88, 537-558.

Megginsion, W. L., R. C. Nash, and M. V. Randenborgh, 1994, "The Financial and Operating Performance of Newly Privatized Firms: An International Empirical Analysis," Journal of Finance, 49, 403-452.

Ohlson, J. A., 1980, "Financial Ratios and the Probabilistic Prediction of Bankruptcy," Journal of Accounting Research, 18, 109-131.

Ongena, S., D. C. Smith, and D. Michalsen, 2003, "Firms and their Distressed Banks: Lessons from the Norwegian Banking Crisis," Journal of Financial Economics, 67, $81-112$.

Rajan, R. G., and L. Zingales, 1998, "Financial Dependence and Growth," The American Economic Review, 88, 559-586.

Shumway, T., 2001, "Forecasting Bankruptcy More Accurately: A Simple Hazard Model," Journal of Business, 74, 101-124.

Slovin, M. B., M. E. Sushka, and J. A. Polonchek, 1993, "The Value of Bank Durability: Borrowers as Bank Stakeholders," Journal of Finance, 48, 247-266.

Titman, S., and R. Wessel, 1988, "The Determinants of Capital Structure," Journal of Finance, 43, 1-19. 
Westgaard, S., and N. van der Wijst, 2001, "Default Probabilities in a Corporate Bank Portfolio: A Logistic Model Approach," European Journal of Operational Research, $135,338-349$.

Yamori, N., and A. Murakami, 1999, "Does Bank Relationship have an Economic Value? The Effect of Main Bank Failure on Client Firms," Economics Letters, 65, $115-120$.

Table 1 - Testable Predictions

Here subscript A (B) refers to the ratio after (before) the bank crash.

Characteristics $\quad$ Proxies $\quad$ Predicted relationship

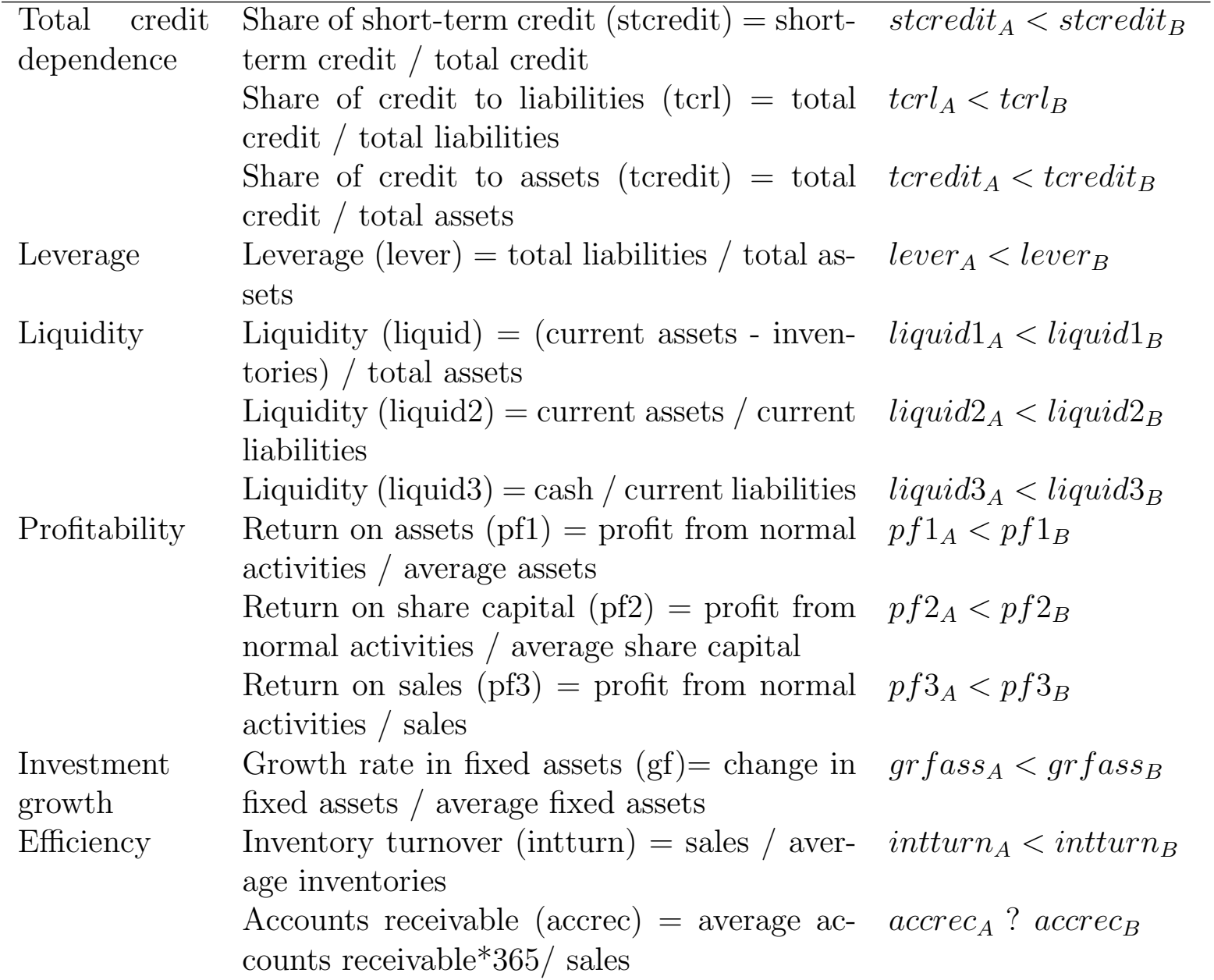


Table 2-Summary Statistics

Sales and profits are given in millions of 1997 Estonian kroons

\begin{tabular}{lcccc}
\hline \hline & Treatment group & \multicolumn{3}{c}{ Control group } \\
\hline Variable & Mean & Std. Dev. & Mean & Std. Dev. \\
\hline Industry structure & & & & \\
$\quad$ Agriculture & 6.72 & 25.15 & 7.02 & 25.66 \\
$\quad$ Manufacturing & 40.34 & 49.26 & 40.35 & 49.28 \\
$\quad$ Trade & 34.45 & 47.72 & 34.21 & 47.65 \\
$\quad$ Transport & 5.04 & 21.97 & 5.26 & 22.43 \\
$\quad$ Real estate & 8.4 & 27.86 & 8.77 & 28.41 \\
$\quad$ Other & 5.04 & 21.97 & 4.39 & 20.57 \\
Sales & 24,3 & 92,7 & 15,4 & 40,6 \\
Profit from normal operations & 0,3 & 1,9 & $-0,1$ & 3,5 \\
Share of firms exporting & 43.70 & 0.5 & 52.63 & 0.5 \\
Age (in years) & 6,3 & 11,2 & 6,5 & 12,9 \\
Number of firms & 119 & & 114 & \\
\hline
\end{tabular}


TABle 3-Logit Results for Firm Survival

Both regressions include the industry dummies. Standard errors are in brackets. ***, ** and ${ }^{*}$ Measures significance at the 1,5 and 10 percent level respectively.

\begin{tabular}{|c|c|c|}
\hline & $\frac{\text { Logit of Survival }}{(1)}$ & $\frac{\text { Hazard for Exit }}{(2)}$ \\
\hline Treatment dummy & $\begin{array}{l}-2.42 \\
(.701)^{* * *}\end{array}$ & \\
\hline Profit to assets in 1997 & $\begin{array}{l}2.317 \\
(1.325)^{*}\end{array}$ & $\begin{array}{r}-1.02 \\
(.963)\end{array}$ \\
\hline Firm leverage in 1997 & $\begin{array}{c}-1.084 \\
(.831)\end{array}$ & $\begin{array}{l}1.47 \\
(.667)^{* *}\end{array}$ \\
\hline Log of sales in 1997 & $\begin{array}{l}-.391 \\
(.15)^{* * *}\end{array}$ & .311 \\
\hline Firms established in 1996-97 dummy & $\begin{array}{l}-1.622 \\
(.815)^{* *}\end{array}$ & $\begin{array}{l}1.051 \\
(.563)^{*}\end{array}$ \\
\hline 1998 year dummy & & $\begin{array}{l}.877 \\
(1.357)\end{array}$ \\
\hline 1999 year dummy & & $\begin{array}{l}.328 \\
(1.557)\end{array}$ \\
\hline 2000 year dummy & & $\begin{array}{l}2.081 \\
(1.301)\end{array}$ \\
\hline $\begin{array}{l}\text { Interaction term between year } 1997 \\
\text { and Treatment dummy }\end{array}$ & & $\begin{array}{l}2.618 \\
(1.19)^{* *}\end{array}$ \\
\hline $\begin{array}{l}\text { Interaction term between year } 1998 \\
\text { and Treatment dummy }\end{array}$ & & $\begin{array}{l}1.988 \\
(.915)^{* *}\end{array}$ \\
\hline $\begin{array}{l}\text { Interaction term between year } 1999 \\
\text { and Treatment dummy }\end{array}$ & & $\begin{array}{l}2.766 \\
(1.203)^{* *}\end{array}$ \\
\hline $\begin{array}{l}\text { Interaction term between year } 2000 \\
\text { and Treatment dummy }\end{array}$ & & $\begin{array}{l}.399 \\
(.799)\end{array}$ \\
\hline Const. & $\begin{array}{l}10.942 \\
(2.752)^{* * *}\end{array}$ & $\begin{array}{c}-11.4 \\
(2.325)^{* * *}\end{array}$ \\
\hline $\begin{array}{l}\text { Obs. } \\
\text { e(r2-p) }\end{array}$ & $\begin{array}{l}201 \\
.27\end{array}$ & $\begin{array}{l}751 \\
.169\end{array}$ \\
\hline
\end{tabular}


TABLE 4-STLS ESTIMATION RESULTS

\begin{tabular}{lcccc}
\hline \hline & Profitability & $\begin{array}{c}\text { Growth rate } \\
\text { of fixed assets }\end{array}$ & Liquidity & Leverage \\
\cline { 2 - 5 } & $(1)$ & $(2)$ & $(3)$ & $(4)$ \\
\hline Treatment dummy & -.073 & .117 & -.059 & .028 \\
& $(.021)^{* * *}$ & $(.107)$ & $(.031)^{* *}$ & $(.050)$ \\
Interaction term between & .017 & -.145 & -.024 & -.003 \\
year 1998 and Treatment dummy & $(.033)$ & $(.132)$ & $(.042)$ & $(.059)$ \\
Interaction term between & .058 & -.012 & -.049 & .099 \\
year 1999 and Treatment dummy & $(.026)^{* *}$ & $(.139)$ & $(.044)$ & $(.068)$ \\
Interaction term between & .076 & -.084 & -.027 & .079 \\
year 2000 and Treatment dummy & $(.034)^{* *}$ & $(.134)$ & $(.047)$ & $(.073)$ \\
Obs. & 922 & 712 & 904 & 917 \\
\hline \hline
\end{tabular}



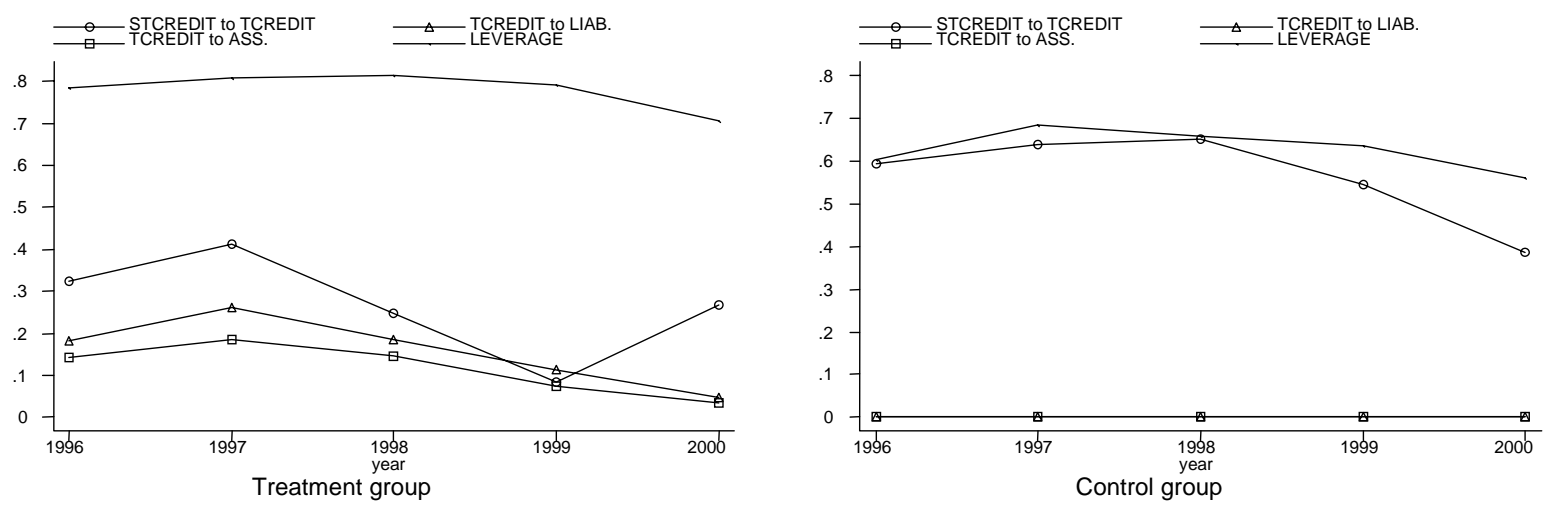

Figure 1. Credit dependence measures (median values)
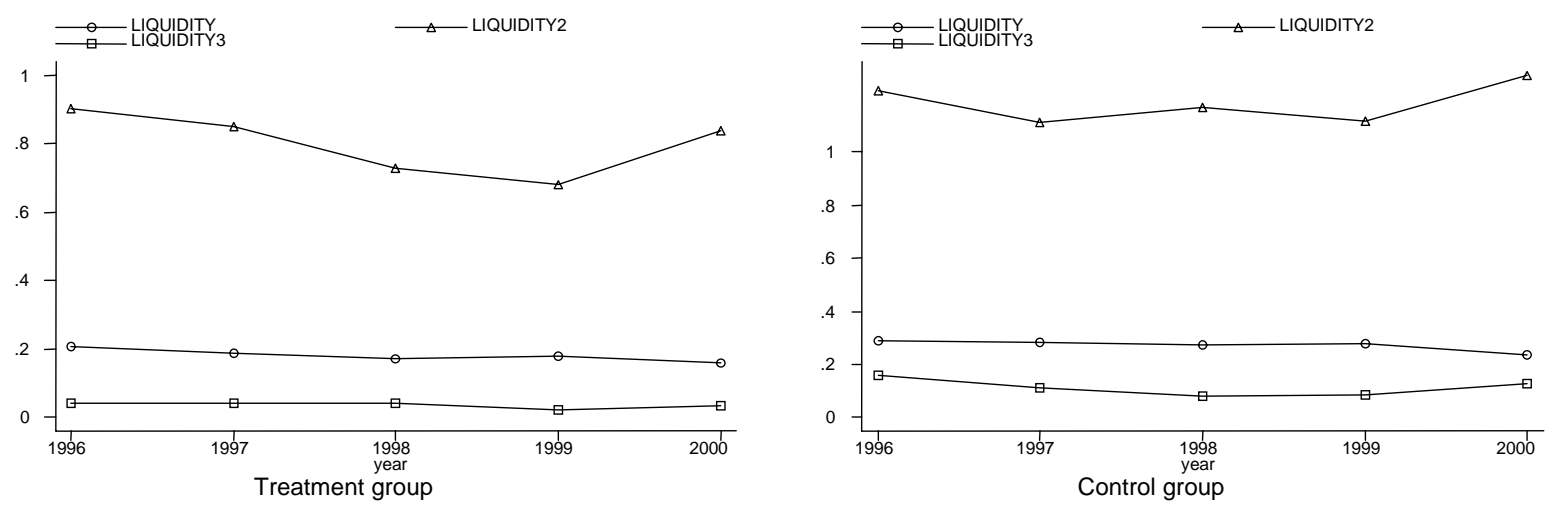

Figure 2. Liquidity measures (median values)
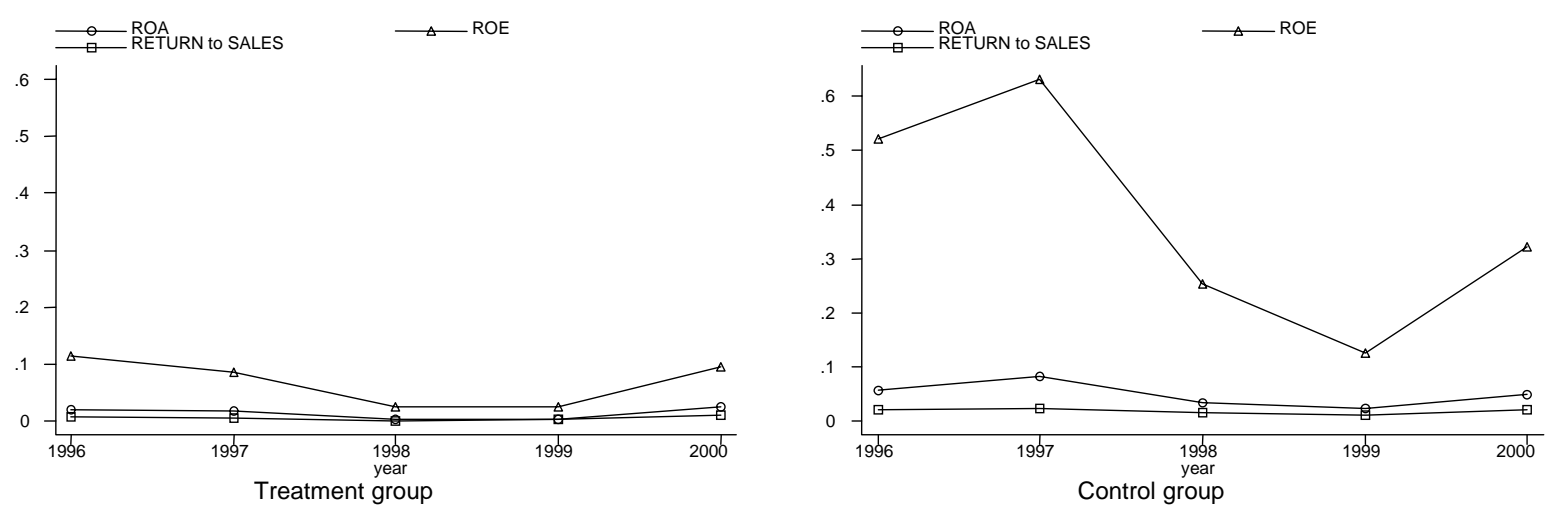

Figure 3. Profitability measures (median values) 

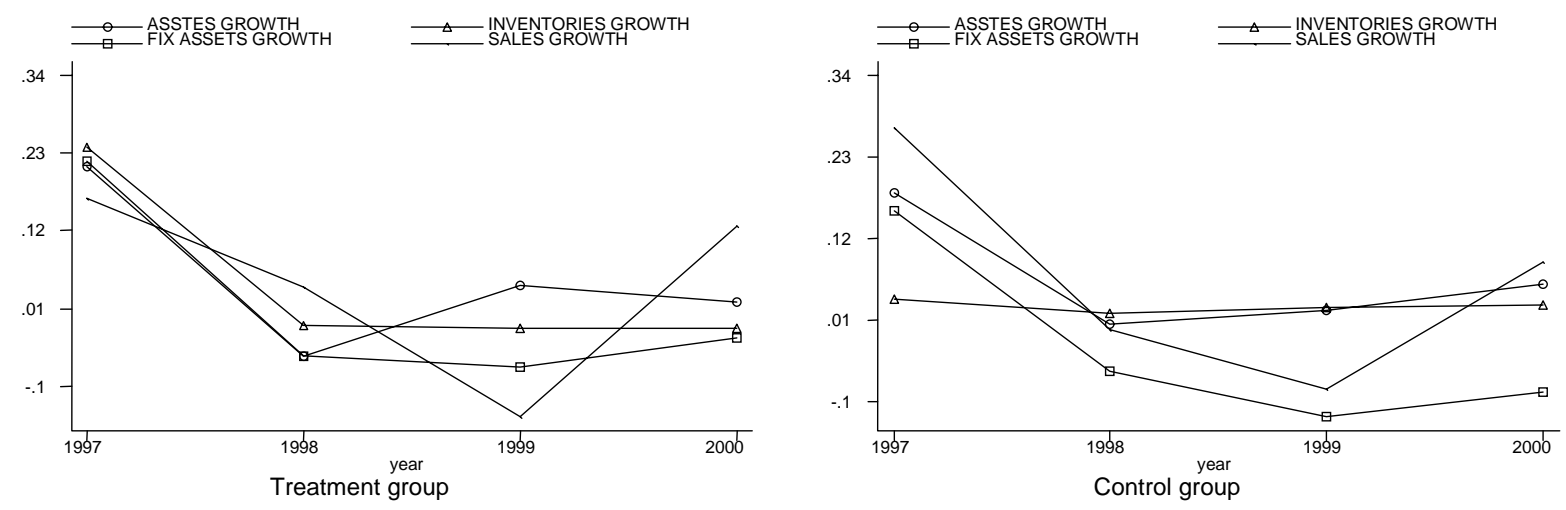

Figure 4. Growth ratios (median values)
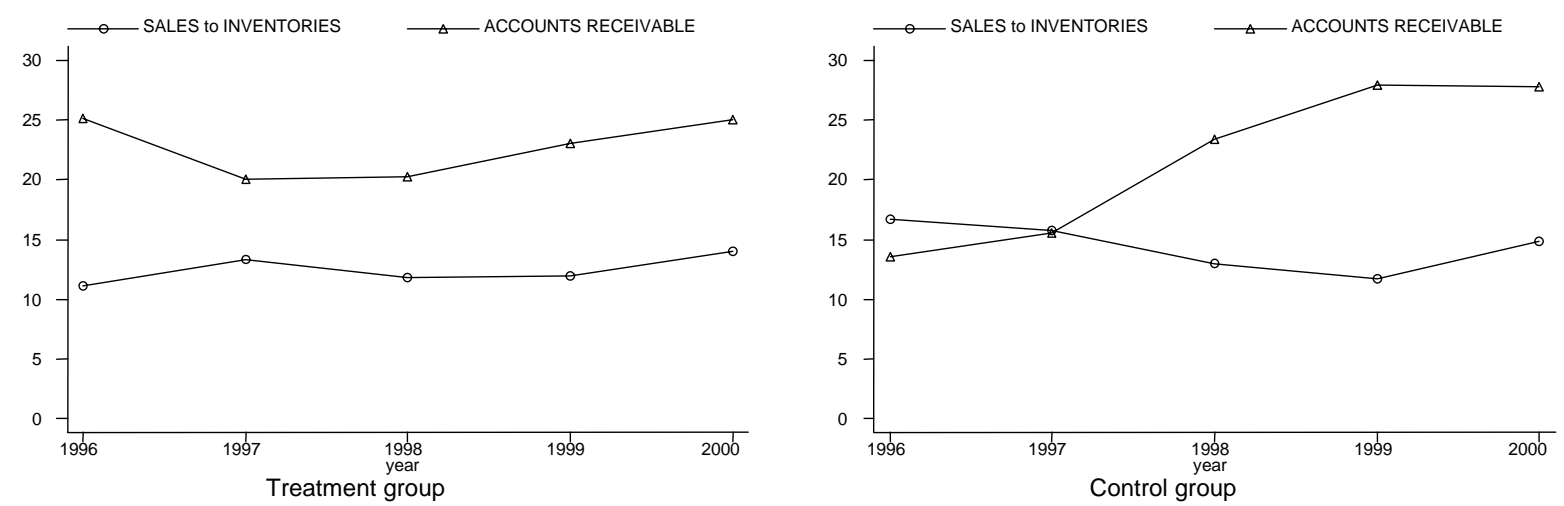

Figure 5. Efficiency measures (median values) 
CERGE-EI

P.O.BOX 882 Politických vezòù 7

11121 Prague 1

Czech Republic http://www.cerge-ei.cz 